\title{
Contemplación en movimiento.
}

18 / 10 / 19: la marcha “+” masiva de la historia en Chile.

\author{
Pablo Venegas Romero \\ Universidad de Valparaíso \\ pablo.venegas@uv.cl
}

Textos bajo licencia Creative Commons Atribución 4.0 Internacional (CC BY 4.0)

La editorial, un texto simple que debe presentar cada número con lo que sucintamente abordan los artículos; no lo es tanto, o no para todos. Es que tiempo ha pasado desde el 18 de octubre de 2019, pero más tiempo ha pasado de lo que se demanda como justo y digno para todos; meses desde esa fecha, años y generaciones desde que hoy sabemos que se puede. En estos tiempos de conmoción se ha instalado ese límite, y aquello nos ha dejado reflexiones inundadas de honestidad o de la necesidad de libertad con una mirada “+” íntegra y franca. En este plano y con la libertad que plantea el momento, me permito escribir con ciertas licencias gramaticales como un signo reflejo de lo que acontece ("+"). Abstraerse de lo sucedido para realizar las actividades ordinarias sin afección, ha sido un acto complejo; seguir considerando lo que a diario determinamos como urgente, para dejar de pensar en lo importante, una polémica.

Enfrentarse al texto condujo entonces inexorablemente a pensar en lo que a todos nos afecta; ha sido difícil desconectarse, dejar de ser honesto y por el contrario volver a vincularse un minuto a lo cotidiano.

Pero nos detuvimos, y unos cuantos días; a pensar-nos y entender-nos, a debatir, y en ocasiones a enfrentarnos, lo que trajo consigo desajustes y cambios en las prioridades. Sin embargo, esta inflexión en Chile también dispuso un estado de esperanza que permite continuar con nuestras labores. En lo personal, me parece que la coyuntura nos deja conscientes de que podemos parar un rato las máquinas para proponerse mejorar nuestro entorno y condiciones; un análisis necesario, pero para otro espacio.

Análogamente, cumplimos entonces con nuestro principal cometido y observamos como los manuscritos de esta edición construyen realidad derivada del análisis, de la reflexión y del estudio de ciertos contextos y circunstancias que escapan a la contingencia actual, pero siempre con relevancia sobre cada ámbito.

Cuando lo lúdico pareciera convertirse definitivamente en estrategia y el juego una manera de mejorar procedimientos, Diego Maté pone en tensión los modos de funcionamiento de los games que se inscriben dentro de la clasificación del art game, analizando tres casos que le permitieron observar distintas formas en las que el videojuego pone en tensión funcionamientos lúdicos y exploratorios, y en esa sintonía, diferentes maneras de representación y de actualización del acto de caminar. A continuación, las palabras nos sitúan en el momento histórico del desarrollo del surrealismo y su vinculación con el arte primitivista a través de la visión integradora que tuvo Wolfgang Paalen, un artista austriaco de relevancia fundamentalmente para el acontecer mexicano y latinoamericano. El trabajo de Araceli Barbosa ubica la reflexión en el ámbito de la valoración artística del arte amerindio dentro del contexto universal del arte en general. Por otro lado, Javiera Larraín retrocede menos tiempo en la historia para recordar la celebración del bicentenario de la independencia 
de Chile, y analizar la relectura que hace el director Guillermo Calderón con la puesta en escena de la obra escrita por Isidora Aguirre y originalmente estrenada en 1969, Los que van quedando en el camino, en el marco del Festival Internacional Santiago a Mil el año 2010; un trabajo que versa sobre uno de los autores más importantes de las últimas décadas dentro de nuestra escena nacional, y alabado también en el extranjero. Como fuente constante de investigación "la imagen" aparece en el artículo de Irene Gras, quien busca constatar cómo, dentro del ámbito de los magazines y semanarios ilustrados de Buenos Aires de finales del siglo XIX y principios del siglo XX, la obra del artista catalán Francisco Fortuny Masagué recrea un imaginario urbano y social vinculado a la modernidad de una metrópoli en desarrollo, participando además en la elaboración de imágenes didácticas que conectan con el pasado histórico e impulsan el nacionalismo. Finalmente, María Rosario García-Huidobro nos relata la experiencia del curso Dibujo Deconstructivo, desarrollado en la Universidad de Los Lagos, y que fuese presentada en el VII Congreso Internacional de Educación y Aprendizaje, Université Paris Dider, en Paris el año 2018, con el propósito de analizar y replantear nociones tradicionales del dibujo en contextos de aprendizajes, con base en el pensamiento de Jaques Derrida.

Como en el número anterior vemos entre los textos que aparece la imagen como un factor relevante de análisis en el ámbito de las artes, y a modo de colofón, particularmente desde el ejercicio del dibujo, un acto no solo plástico asimismo intelectual, que desborda el núcleo de todo proceso de aprendizaje pues involucra siempre una actitud y cultiva valores como la paciencia y perseverancia, factores que parecieran ir desapareciendo de nuestro escenario natural, paulatinamente; el dibujo sigue siendo una actividad que estimula la observación, un proceso de tempo moderado, distinta del mirar que con celeridad completa la acción.

Ciertamente los procesos y procedimientos de esta edición se vieron afectados en participación y tiempos como todo. No obstante, el compromiso precisó seguir adelante, pero con espacio para la reflexión a ojos del arte que no puede ni debe evitar tener presencia en lo que acontece. Por esta razón el inciso se presenta en versión compartida, exponiendo el instante a través de la mirada de un colectivo de ilustradores que -redundando- ilustraron el momento; y de un ensayo visual que mira el espacio social bajo la perspectiva histórica que evidencia el habitar chileno antes y después a la dictadura cívico militar; las condiciones de futuro vistas desde el pasado. El inciso -desligado de lo que los artículos tratan-, deja espacio para esa honestidad que las circunstancias hicieron oportuna, reconociendo que la crisis social hoy se exhibe con vehemencia e intensidad en la manifestación pública. Como resumen imaginario tendremos uno de los momentos “+” importantes de la historia de Chile, quizás el “+” luego de los “9os, expresado en las imágenes aéreas que dejó la marcha del 25 de octubre de 2019, la que independiente del número preciso de participantes es has- ta hoy considerada como la "+" masiva también en nuestra historia (para quienes no la han visto por favor googlear).

Desconozco si incurro en un exabrupto al hacer un guiño o mencionar lo citado; sin embargo, está el espacio y me debo a éste con sensibilidad más que con imparcialidad; la opinión nos hace participativos antes que parciales. Así como nos parece importantísimo que el arte y la investigación artística tengan un lugar en la esfera de la investigación a secas, es necesario y honesto el que lo sucedido se siga comentando para alimentar la esperanza.

Finalmente es relevante mencionar que el desarrollo de los artículos evidencia con solidez que la investigación artística requiere de magnitudes más propias de la contemplación que de las certezas, de análisis profundos y con espacios a consideraciones que no pueden escapar de la singularidad humana, y ello nos deja con un sabor de texto dulce que confiere un estado de ánimo en el cual apreciamos como posible y necesaria la valorización de las disciplinas que nos enmarcan, próximas siempre a métodos de dimensiones creativas.
Pablo Venegas Romero Editor en Jefe 